\title{
China and the West: Contestations in African Development and Security
}

Napoleon Kurantin and Bertha Z. Osei-Hwedie*

\begin{abstract}
The article critically examines the second wave of the contestation and/or scramble for Africa's natural resources. The scramble for the Africa's economic resources by the European countries that started in the colonial period never ceased even after decolonization. The current situation is the emergence of a new non-traditional imperial power - China. The paper investigates this dimension relative to Africa's former colonial masters and traditional trading partners within the comity of nations. Within the context of development - security nexus and relative to geo-politics, Afro-Chinese relationship may not be the best model of multilateral/bilateral frameworks elsewhere in the world. However, Afro-China relationship is distinct in important ways when compared with Western nation-states. The Chinese have elevated the belief that long-term development of the African continent requires and hinges upon security and that lasting security depends upon development. Thus, the security and development nexus concern a general idea of how societal security and development is best achieved and maintained and how both the civil and military should form a cohesive approach in international cooperation towards Sustainable Development Goals. This paper applies a mixed methodological approach, including quantitative and qualitative methods, to examine this subject with view to evaluate the impact of Africa's relations with China and whether African aspiration for development can be leveraged through this relationship.
\end{abstract}

Keywords: Game theory, Human security, Liberalism, Nash equilibrium, Neo-liberalism, Realism, Security - development nexus, Sustainable development goals.

* Dr. Napoleon Kurantin and Prof. Bertha Z. Osei-Hwedie are with Ghana Institute of Management and Public Administration, School of Public Service and Governance, Accra, Ghana. 


\section{China and the West: Contestations in African Development and Security}

\section{Introduction}

The manifestation of China in international politics has indeed left an indelible mark on Africa's processes of security guarantee and economic development. Historically, China's relationship with Africa has been shaped by colonial struggles of 1950's and the spirit behind South-South cooperation. In recent times, China's foreign policy towards Africa is geared towards efforts in capacity-building for maintaining and strengthening peace, security and support Africa in its quest to speed up the processes of achieving the Sustainable Development Goals (SDGs) and hence, eradicate poverty. The ever-increasing China's interests in Africa in the $21^{\text {st }}$ century has been embraced by open arms by many African leaders who see it as an opportunity to kick-start and enhance economic "take-off", serving as platform to leverage their bargaining position relative to their former colonial masters and, traditional western donors and to enhance Africa's collective voice in the comity of nations. It's important to note that China's engagement has mostly been intensified in the economic and infrastructure sectors with increasing postulations in the area of security and the processes of socio-economic development. The article critically examines the second wave of the contestation and/or scramble for Africa's natural resources. The scramble for the Africa's economic resources by the European countries that started in the colonial period never ceased even after decolonization. The current situation is the emergence of a new non-traditional imperial power - China. However, China is distinct in important ways from western nation-states. Although the burgeoning appetite is to secure the state hegemony interest within the realm of international relations, China, has position itself as an emerging power projecting its foreign policy relatively away from western traditional principle of non-interference kind of engagement to a more strings attached engagement underpin by the security-development nexus with African states. The inquiry is divided into an introduction, literature review and theoretical framework, data requirement, methodology and method, discussions and conclusions. 


\section{Literature Review and Theoretical Framework}

Increasingly, the nexus between security and development is taking center stage relative to both national and the global community of policy makers. Relations among states as is understood emanates from different dimensions with interactions among noted actors that ranges from the individual to nation-states, international organisations, and multinational corporations. Henceforth, it thus, in the words of Tema (Tema, 2014):

....follows that game theory, whose main goal is the formalized analysis of decisionmaking procedures and relationships among two or more actors, can assist international relations theoreticians and practitioners in the field in order to explain the interactions among the actors it considers. Therefore, game theory provides specific means not only for understanding different realities but also means in order to influence interactions with broad benefits.

Game theory unfolds a comprehensive method that allows in-depth explorations of different political, social, and economic interactions. Given the actors basic preferences related to respective utility and given their strategic environment, game theory helps us to infer how they rank the various actions at their disposal and furthermore it helps us to determine the expected outcomes of the interplay of specific choice

As Tema (2014) further observes, within the "discipline of International Relations there are competing theories or theoretical perspectives. In this context, realism is a specific approach of international policies that stresses the competitive and conflictual aspects of the international system". At the core of the realist assumptions, as Ray (2003) and Tema (2014) observe, is the belief that "the state is the key actor in international security", development, "politics and relations among states". This stance is contradicted by idealism or liberalism which has a general predisposition to emphasize non-state actors and co-operation. In a sharp contrast to the liberalist thought, the realist school of thought considers the principal actors in the geo-political sphere to be that of nation-states pursuing their own national interest particularly, that of national security. Therefore, the basis of national security is the accumulation of harder and/or soft power.

Speaking of Realism, Badie, Schlosser and Morlino (Badie, Schlosser \& Morlino, 2011) find that: 


\begin{abstract}
"The classical realists from Thucydides onward described an international state of war that could be mitigated, but not overcome, short of a world Leviathan. The classical liberals, with important variations, broke with this skeptical tradition and announced the possibility of a state of peace among independent, sovereign states. Contemporary scholarship on liberalism and international relations looks back at three distinct traditions of liberalism, attributable to three groups of theorists: John Locke (1689), the great founder of modern liberal individualism, who claimed that states have themselves rights derived from individual rights to life and liberty (political independence) and property (territorial integrity), thereby providing the liberal foundations of international law; Adam Smith (1776), Baron de Montesquieu (1748), and Joseph Schumpeter (1947), brilliant explicators of commercial liberalism and what they saw as its natural result, liberal pacifism; and finally, Immanuel Kant (1781), and Giuseppe Mazzini (1860), liberal republicans who theorized an internationalism that institutes peace among fellow liberal republics. The liberal republican tradition, while incorporating to some degree both liberal individualism and commercial liberalism, has exerted the greatest influence on contemporary liberal international relations theory. It argues that liberal democracy leaves a coherent international legacy on foreign affairs: a separate peace. Liberal states are peaceful with each other, but they are also prone to make war on non-liberal states".
\end{abstract}

Majority of neo-liberal analysts rely on the rational choice and game theory models, borrowed from the realm and discipline of economics. Prior to the emerged thinking of the interrelationship between security and development, security studies focused their attention around the control, threat and/or use of force. According to Bernard (1998) "The prevailing view was that since states are both the main users of force and the main targets of force, security should therefore, be state centric and military centric". Henceforth, Bernard (1998) and Baylis (2001) say, "as a result of this understanding, security came to be understood as mainly related to the state and/or the military".

Writing on the same subject, Anderson (2012), suggests that, "threats have traditionally been thought to comprise some combination of the capability and intent to do harm, both being required to constitute a threat. The focus on the state, the military and external threats was later criticized for being too narrow and not functional with the realities of today". 
Accordingly, the "new paradigms of security studies have tended to eliminate this important element of intent or agency, and have securitized a wide range of threats that lack this qualification. The process that was referred to above as securitizing have come to frame what includes environmental decline, natural disasters, poverty, deadly diseases and resource scarcity as threats not only to the state itself, but to international security. Thus, the new concepts such as human security espoused and therefore, coined by the United Nations Human Development Report (1994), takes note of this multi-dimensional view of security and includes seven elements of security: economic security, health security, food security, environmental security, personal security, community security, and political security" (Anderson, 2012).

Baldwin (1997) finds that, "The emphasis on national security seen before have not lost importance, but made equally important to international and global security due to the recognition that the world today is interdependent politically, socially and economically".

In the same vein, attempts at defining the concept of the processes of development has not been easy. Different schools of thought have over the years put forward variant and/or dimensions of what they thought constitutes development. Sumner and Tribe (2008) talked of "Johansson (2014), establishes that the meanings of the processes of development have changed from mostly being linked with economy and industrialization in the 1940's, to meaning economic growth, social and political modernization advocated by the modernization theorist's; in the1980's the meaning of the concept development shifted into concerning economic growth and structural adjustment change".

Therefore, as a historical concept, 'development' has been understood as a process of biological evolution, signifying the ultimate fulfilling of the process of becoming what one is 'supposed to be' (Nisbet, 1980). As it were, 'development' became a key strategy for state-building in the postcolonial societies in which there was an urgent need for both economic growth and political consolidation (Simon, 1999). Unfettered belief in modernization through 'development' as a fastest and assured path away from prevailing 'underdevelopment' followed suit (Rostow, 1962; de Janvry \& Kanbur, 2006). The state was the sovereign key actor and 'guarantor' for development (measured in economic terms). Importantly, through 'development' so understood, nation-states 
were to be invented, established, secured and evolved along a linear trajectory of 'progress', following the path forged by former colonial and/or empire power states in Europe.

In the post-development era, the continuous criticism of the notion and processes of development is enhanced by the post-modernism and/or post-colonial hiatus. Thus, the processes of development have no in-built substance. Rather, it was meant to continue with the reproduction of colonial attitudes and power relations between the colonial center and the periphery involving the emerging nation-states within the southern hemisphere. The foci was placed on what was done in the name of development, not on what form of development was desirable. A school of "postdevelopment' emerged (Escobar, 1995; Rahnema, 1997; Esteva, 1992), claiming that the idea of 'development' de facto made substantial, from-within progress impossible, disempowered people, and disrupted existing local power structures, thus creating instability and conflict. Accordingly, 'development' was counter-productive (as in the above account), ethically corrupt, and served to uphold differences and hierarchies. Therefore, 'Development' was seen as the reason for, and guardian of, inequalities between people and societies, not the solution to them (Stern \& Ojendal, 2010 , p.12). As part of the project to investigate and meaningfully understand development, at least two distinctly different counter-narratives came to challenge the mainstream story, serving to broaden, deepen and thus, humanize the processes of development. First, it was countered by a Marxist and/or structuralist fundamental critique, focusing on international power structures in combination with the prevailing capitalist mode of production. This critique was theoretically explained through 'world system theory' (Wallerstein, 1974), and more concretely through 'dependencia' school of thought (Prebisch, 1950; Frank, 1969). These schools forcefully emphasized the structurally exploitative nature of the capitalist world system and its negative impact on the processes of development in southern hemisphere. Because of these factors, it was argued, there was a necessity for poor developing countries to 'delink' and develop through selfsufficiency. Henceforth, the story of (mainstream) development was reversed, yet still teleological, state-centric, and elite-driven. In addition, at the other end of the spectrum, we saw a 'participatory revolution' that emphasized the significance of 'reconnecting' to the true 'subjects' of development, namely, the poor, the local, the grass roots and the voiceless. The shift in focus from state-centric development to 'human' development is perhaps the most profound and durable 
impact that can be traced to these critiques of the dominant development narrative (Pietersee, 2000).

In conclusion, the resultant agreement is that the processes of development involve change or transformation (Sumner \& Tribe, 2008). Thus, emerged and noted concepts such as human development and sustainable development have been embraced by the United Nations in their work against poverty and development. Development according to the Sustainable Development concept is "development which meets the needs of the present without compromising the ability of future generations to meet their own needs" (Drexhage \& Murphy, 2010). Both human development and sustainable development includes various factors that all together effects development. Sustainable development most often includes four dimensions which are: the ecological dimension, the social dimension, the economic dimension and (not always) the political dimension (Johansson, 2014). According to the Brundtland Report, sustainable development is "development that meets the needs of the present without compromising the ability of future generations to meet their own needs" (WCED, 1987, p. 8).

The Center for Strategic and International Studies (CSIS) (2002) and the Association of the United States Army (AUSA) (2002) have developed a framework for the reconstruction of post-conflict situations and, in prevention or emergence of more failed states. The framework is organized around four distinct pillars. The noted pillars involve security, justice/reconciliation, social/economic well-being, and governance/participation. Among the four pillars, social and human economic well-being are vital with security related issues given the utmost priority:

"The framework argues that security addresses all aspects of public safety, in particular establishment of a safe and secure environment and development of legitimate and stable security institutions. Security encompasses the provision of collective and individual security and is the precondition for achieving successful outcomes in the other pillars (Center for Strategic and International Studies \& Association of the United States Army, 2002). On the other hand, social and economic well-being addresses fundamental social and economic needs; in particular provision of emergency relief, restoration of essential services to the population, laying the foundation for a viable economy, and initiation of an inclusive, sustainable development programme." 
According to Chandler (2007), "prior to the security and development nexus paradigm entered the research field, security and development were much more approached as two different sectors with different ideas and aims. There are two reasons behind this change of paradigm. Firstly, the shift is rooted in the belief that by merging security and development closer will create the most coherent and well managed policies with regards to the work in post-conflict countries, failed stead and weak state (Chandler, 2007)."

Secondly, and as aforementioned, there is a belief that long-term development requires and hinges upon security and that lasting security depends upon development (International Peace Academy, 2004, p.1).

There is an increase number of scholars investigating, examining, and analyzing China's security engagement in Africa. However, such scholarship largely views and considers security from a traditional perspective:

“China stands ready to take an active part in Africa's efforts in capacity-building for maintaining and strengthening peace and security and support Africa in its endeavors to speed up development, eradicate poverty and realize durable peace," President Xi Jinping's speech during the Africa-China summit in December, 2015 (Jinping, 2015b). Furthermore, Chinese President Xi Jinping emphasized: "a continuation of this development-security nexus when he stressed that to build security: We need to focus on development, actively improve people's lives and narrow down the wealth gap so as to cement the foundation of security. We need to advance the process of common development and regional integration, foster sound interactions and synchronized progress of regional economic cooperation and security cooperation and promote sustainable security through sustainable development" (Jinping, 2015b). Therefore, this raises the need for a security-development nexus as a framework to understand China's security practices in Africa. Such a nexus highlights the integration of security and development and views peace and conflict resolution to be the result of successful economic development. Chinese official discourse is explicit in tying security promotion and conflict resolution to economic development. For example, Chinese foreign minister Yang Jiechi stated: "We [Chinese policy makers] believe that development is the foundation for peace 
in Africa. Conflict and poverty often come hand in hand and form a vicious cycle. If Africa is to achieve durable peace and stability, it needs to speed up economic and social development and let all the people share the benefits of development" (Benabdallah, 2016, p. 19).

Although the development-security web is more of a Western construct, as such, the concept is not without equivalent in the Chinese context. In fact, China has had over thirty-five years of domestic experience with enhancing security and stability with an emphasis on economic development (Yizhou, 2013). By the turn of the century to 2013, the Chinese nation-state obtained raw materials from overseas to fuel its domestic development agenda. At the same time, massive state-owned organisztions entered the African market. This came alongside the export of Chinese-made goods to Africa with about half a million Chinese migrants flooding the continent (Poplak, 2016).

A classic example, in 2013, Zendai Group of China, announced 4.8 billion pounds real estate development in Modderfontein north-east of Johannesburg, South Africa (Poplak, 2016). As espoused by Poplak (2016), was this not more than an old-school land grab, orchestrated by Beijing in a tidy neo-colonial machination. China's own history with political interference in economic development since the inception of the Chinese Communist Party (CCP) under Mao's rule has resulted in a strong belief in the necessity of economic growth to maintaining internal order. “Under Mao political campaigns such as the decade-long Cultural Revolution undermined China's economic growth and caused turmoil for years to come. By contrast, Deng Xiaoping's regime was characterized by placing economic progress through campaigns such as 'open door policy' at the center of the party's goals" (Poplak, 2016).

Likewise, Hu Jintao came up with the concept of scientific development, and Xi Jinping invented the:

"China Dream, both of which place economic development as the central task of the party Indeed, China's commitment to the development-security nexus approach can be traced back to Deng Xiaoping's vision and plan for China's industrial revolution. During that period, the Chinese Communist Party started implementing development plans that enhanced economic growth and focused on improving living conditions for its citizens by 
creating job opportunities for the youth and reducing poverty levels" (Benabdallah, 2016, p. 20).

These measures were successful on basically three fronts: "they created the economic growth the CCP had targeted, they resulted in more stability and satisfaction among the people, and they brought legitimacy for the $\mathrm{CCP}$ as it was perceived by the people to be efficient in its leadership" (Chris \& Large, 2013). This experience with achieving security based on launching development plans came to shape Chinese officials' conceptualization of the "new security" in the post-Cold War era that was based on a shift from understanding security as self-help to a more mutual/common security:

"This mutual/common view of international security was mainly based on Chinese policy makers being convinced that their methods of enhancing legitimacy of CCP and security at home should also be applicable abroad. Mutual security was viewed as the result of winwin cooperation on economic growth and development projects. For Chinese policy makers, regional and global security could not be achieved by an increase in arms, or by military alliances. Security should be based on mutual trust and common interest...We should solve disputes through peaceful means and strive for common development" (Benabdallah, 2016, p. 20).

International relations, as characterized, among other authors, by Evans and Newnham (1998), Lake and Powell (1999), Reynolds (1994) and Wolfers (1991), deals with the interactions among specific actors which include nation-states, non-state actors including international organizations, and multinational corporations. From this it follows that game theory: "whose main goal is the formalized analysis of relationships among two or more actors, can assist international relations theoreticians in explaining the interactions among the actors it considers, and practitioners in the field to influence those interactions to benefit the actors they represent or, hopefully, all humankind" (Correa, 2001). As eloquently expressed by Poundstone (1993): "game theory and international relations have influenced each other almost since the publication of The Theory of Games and Economic Behavior by von Neumann and Morgenstern (1944), usually considered to be the first systematic and extensive formal analysis of social interactions." Furthermore, Bennett 
and Nicholson (1994) indicate that this interaction has been both friendly and conflictive, and considered by some to be constructive and by others destructive.

Von Neumann's and Morgenstern's (1944), applied game theory with the possibility that: "the game can be played without having a well-defined expectation about when it will end, a condition that can be exemplified with the negotiations to end the Korean War, and when the pay-offs of the players for settling their disagreement or for breaking off the negotiation are not known with certainty." Similarly, Dixit and Skeath (1999), present: "an application of some of the game theoretic instruments mentioned above to the study of U.S.-Japan trade negotiations. This particular investigation and analysis is particularly interesting in that it is especially attentive to the promises and threats that the actors can make to each other, and the impact that these pledges can have on the interacting nation-states." Mishall, Schmeidler and Sened (1990), applied game theory with differential information to an analysis in formulating on the Israeli-Palestine Liberation Organisation (PLO) conflict: "the conflict between Israel and the Palestinians is over territories west of the Jordan River and over the level of self-government by the Palestinians in some of these territories. An incomplete information game without the consistency assumption is referred to as a game with differential information."

To prevent and/or avoid the process of designing a model in an analysis of Israeli-PLO conflict becoming an infinite one, some restrictions are: "imposed on the process of enumerating available policies. Mishall, Schmeidler and Sened (1990), continue the procedure of elimination and inference, try to infer from these premises the policies that should be taken into account in a formalization of a strategic game." In addition, Mishall, Schmeidler and Sened (1990), observes that:

"the premises rule out a policy of unilateral and unequivocal recognition of Israel and public renouncement of the armed struggle prior to the establishment of a Palestinian State in the West Bank, or at least prior to the achievement of some tangible political and territorial gains. Henceforth, it leaves one with three possible policies: (I). Yes/No policy emphasizes the political process with a possible compromise on armed struggle and unity (Mishal, 1986, p. 150). The PLO might be willing temporarily to cease, or to minimize, the armed resistance at the price of friction and dispute within the organization. At the same 
time, the PLO would be reluctant to participate in direct negotiations unless clear cut territorial gains were guaranteed a priori; (II). No/Yes policy emphasizes the armed struggle while allowing, to some extent, diplomatic activity (Agha, 1976, p. 20). Since diplomatic activity, according to this policy is regarded as a tactical means of achieving the ultimate goal rather than a strategy to achieve an agreement, the PLO would be very reluctant to lower the intensity of its armed struggle; and, (III). No policy emphasizes the willingness to sacrifice possible political gains in favor of intensive reliance on armed struggle. Attributing little, if any, benefit in the short run to the political process, such a policy will tend to amplify the armed resistance, regarding it as the sole means of achieving PLO political goals (Garfinkle, 1983, pp. 631-638).”

Putting ourselves in the place of each type and keeping in mind all that was said up to here, we suggest the von Neumann-Morgenstern utilities each type attributes to any of the possible outcomes: "It is useful, in this context, to clarify further the costs and benefits associated with each possible outcome. Benefits refer to the extent to which each of the outcomes advances the political interest of each type; costs refer to the political price that each type will have to pay for the concessions required by each outcome. The evaluation of benefits depends on each type set of priorities (Garfinkle, 1983, pp. 631-638).”

From the spectrum of opinions in each of the two camps we restrict our attention to two representative types for each player. Rather than adopt the misleading nom-enclature of "doves" and "hawks," we use the terms "minimalists" and "maximalists" (NM). Note, however, that: “according to our methodological approach, a player's type is completely characterized by his NM utilities over outcomes and his probabilistic beliefs over the other players' types. The minimalist type of each player is ready to consider the possibility of a settlement that accords certain territorial and/or political gains to the other player. Both also believe that NS is a significant step toward which both oppose" (Mishall, Schmeidler \& Sened, 1990, pp. 347-348). Restrictions on $\beta$ and $\delta$ are used in the computation of the equilibria. It's to be noted that there is a need not to impose restrictions on $\alpha$ and $\gamma$ relative to the computation of Nash equilibria ${ }^{1}$ (Ohlin, 2011),

\footnotetext{
1 Nash Equilibrium: named after the mathematician John Forbes Nash Jr. is a proposed solution of a non-cooperative game involving two or more players in which each player is assumed to know the equilibrium strategies of the other players, and
} 
Henceforth, a noted obstacle for the application of the model outlined here to actual negotiation processes is raised as a consequence of what can be called a structural defect of game theory: it provides, at best, very limited guidance for the specification of the pay-offs that the negotiating nation-states should receive when they select each of the strategies, they have available. It is simply assumed that certain or uncertain information about pay-offs is available.

From the above analysis, it is obvious that it is emerging that there is a consensus in the literature that 'security' and 'development' are interconnected, and that their interrelationship is growing in significance given the evolving global political-economic landscape.

\section{Research Data Requirement, Methodology and Method}

To comprehensively research, understand and therefore, contribute to the synthesis of China's strategic interest, role and how they impact practical and ideational processes of security development nexus of the African continent strives towards development (SDGs) relative to its former colonial masters and hence, traditional partners, the study will adopt a mixed methodological approach. The emphasis of a mixed methodological approach is its focus on: "collecting, analyzing, and mixing both quantitative and qualitative data in a single study or series of studies. Its central premise is that the use of quantitative and qualitative approaches, in combination, provides a better understanding of research problems than either approach alone" (DeVellis, 2003).

Heyvaert, Maes and Onghena (2011), espouse that: "a mixed methodological research can be applied at the primary empirical study level as well as at the synthesis level. Thus, at the primary level, mixed methods study allows and enables a researcher to collect both qualitative and

no player has anything to gain by changing only their own strategy. In terms of game theory, if each player has chosen a strategy, and no player can benefit by changing strategies while the other players keep theirs unchanged, then the current set of strategy choices and their corresponding payoffs constitutes a Nash equilibrium. Stated simply, Alice and Bob are in Nash equilibrium if Alice is making the best decision she can, taking into account Bob's decision while his decision remains unchanged, and Bob is making the best decision he can, taking into account Alice's decision while her decision remains unchanged. Likewise, a group of players are in Nash equilibrium if each one is making the best decision possible, taking into account the decisions of the others in the game as long as the other parties' decisions remain unchanged. Nash showed that there is a Nash equilibrium for every finite game Guiherme, C. \& Konrad, P. (2009). On the Existence of Pure Strategy Nash Equiibria in Large Games. Journal of Economic Theory, 144(3), 1300 - 1319. 
quantitative data directly from the research participants, for example through interviews, observations, and questionnaires, and combines these diverse data in a single study. A synthesis level mixed methods study is a systematic review that applies the principles of mixed methods research." This type of research is referred to: "as a systematic review by the notion 'mixed methods research synthesis' (MMRS). As a method, it focuses on collecting, analyzing, and mixing both quantitative and qualitative data in a single study or series of studies. Its central premise is that the use of quantitative and qualitative approaches, in combination, provides a better understanding of research problems than either approach alone. Henceforth, in such a synthesis, the data to be included in the review are findings extracted from several published qualitative, quantitative, and mixed primary level inquiry. A mixed methods approach combining qualitative and quantitative research elements is used to integrate these qualitative and quantitative research findings within a single systematic review and/or project."

Shank (2002, p.5), defines qualitative research as "a form of systematic empirical inquiry into meaning." Within this context, systematic means "planned, ordered and public," following rules agreed upon by members of the qualitative research community. On the other hand, empirical, means that this type of inquiry is grounded in the world of experience. Inquiry into meaning adheres to the fact that researchers try to understand how others make sense of their experience." Denzin and Lincoln (2000, p. 3), claim that qualitative research involves an interpretive and naturalistic approach: "This means that qualitative researchers study things in their natural settings, attempting to make sense of, or to interpret, phenomena in terms of the meanings people bring to them." Ary, et. al. (2006) further explains that "the qualitative researcher understands human behaviour through the meanings of events that people are involved in. The constructivist researcher does not only consider people but considers how people think and feel and the experiences that have happened to them (ibid). These practices, as Denzin and Lincoln (2008) pointed out, have transformed the world from the positivist position."

Historical research, content analysis and case study as noted methods within qualitative research approach are applied in achieving the goal and objectives of this study. Historical research: "has been defined as the systematic and objective location, evaluation and synthesis of evidence in order to establish facts and draw conclusions about past events (Shafer, 1974).” It involves a critical 
inquiry of a previous age with the aim of reconstructing a faithful representation of the past. According to Garraghan (1946), and Shafer (1994):

"in historical research, the investigator studies documents and other sources that contain facts concerning the research theme with the objective of achieving better understanding of present policies, practices, problems and institutions. An attempt is made to examine past events or combinations of events and establish facts in order to arrive at conclusions concerning past events or predict future events. Historical research is a type of analytical research. Its common methodological characteristics include (i) identifying a research topic that addresses past events, (ii) review of primary and secondary data, (iii) systematic collection and objective evaluation of data related to past occurrences with the help of techniques of criticism for historical searches and evaluation of the information and (iv) synthesis and explanation of findings in order to test hypotheses concerning causes, effects or trends of these events that may help to explain present events and anticipate future events (Gottschalk, 1951). Historical studies attempt to provide information and understanding of past historical, legal and policy events."

As a research endeavor, the case study contributes uniquely to our knowledge of individual, organizational, social, and political phenomena. Case study as a qualitative method involves the detailed examination of a single example of a class of phenomena, it may be useful in the preliminary stages of an investigation since it provides hypotheses, which may be tested systematically with a larger number of cases (Conrad \& Serlin, 2006). In addition, Yin (1984), explained: "case study more technically as a case study is an empirical inquiry that investigates a contemporary phenomenon within its real-life context; when the boundaries between phenomenon and context are not clear; and in which multiple sources are used. Moreover, Stake (1995), described a case study may be understood as the intensive study of a single case where the purpose of the study is - at least in part- to shed light on larger classes of cases. Furthermore, Yin (1994), points out that generalization of results, from either single or multiple designs, is made to theory and not to populations. Thus, case study evaluations can cover both process and outcomes, because they can include both quantitative and qualitative data." 
In the case of using qualitative content analysis in case study research, triangulation takes actually place on two different levels: "on the first and more obvious level, data is triangulated by integrating different material and evidence is often also collected by using various methods-as well as by integrating quantitative and qualitative steps of analysis. On second level, triangulation takes place by applying a method of analysis (qualitative content analysis) that has not been particularly developed for this purpose to a different research design (case study research) (Hamel, 1993)." Thus, in general a content analysis is applied when the researcher wants to systematically describe the content of a material (Bergström \& Boréus, 2005, p.50). "A content analysis can be of both a quantitative and/or qualitative character (Werle \& Andersson, 2012, p. 15). Research using qualitative content analysis focuses on the characteristics of language as communication with attention to the content or contextual meaning of the text whilst a quantitative content analysis focuses more on the frequency of words in a document (Hsieh \& Shannon, 2005, p.1278).”

Quantitative research approach uses objective measurements and statistical analyses of numeric data to understand and explain a phenomenon (Ary, et. al., 2006). It is originated in positivism:

"The positivist emphasizes measurement to gather data with objective techniques to answer questions. It is a research that is systematic and open to replication by other investigators (ibid). According to, say, Evans and Newnham (1998, p. 645) and Hollis and Smith (1990, p. 10), one of the basic assumptions of the realist approach to international relations is that nation-states are motivated only by their own interests. This school of thought emphasizes that nation-states consider the needs and interests of other nation-states only when the other nation-states have the capability to enforce their demands by threatening or performing damaging actions. This means that nation-states are not guided by ethical or humanitarian considerations, and that international law and even treaties and similar formalized agreements do not really restrict the international activities of nation-states. It is particularly interesting to consider these observations from the point of view of game theory as a method within quantitative methodology. A basic and much criticized assumption of this discipline when applied to social interactions is that the actors involved are completely self-centered and tirelessly pursuing only their own satisfaction. Game theory finds in the nation-states as described above the closest real-life examples of its abstract constructs. This is the true regardless of whether they are interacting with respect 
to security, development and/or to economic issues (Brans, 1975; Bierman \& Fernandez, 1998)."

In game theory, rationality demands that: "each actor tries to maximize gains or minimize losses under conditions of uncertainty and incomplete information which required each actor to rank order preferences, estimate probabilities, and try to determine and predict what the other actor is going to do. In a two-person zero-sum game, what one actor wins the other loses; if $\mathrm{x}$ wins 10, $\mathrm{y}$ loses 10 , therefore, the sum is zero. On the other hand, in a two-person non-zero or variable sum game, gains and losses are not necessarily equal. In this kind of games, it is possible that both sides may gain. These games are sometimes referred to positive-sum games. In such games, it is possible that both sides gain. These games are sometimes referred to as positive-sum games." In some games both parties can lose to a different degree. The so-called n-person games include more than two actors in a play: "In game theory a game matrix represents a strategic situation in terms of choices that must be made simultaneously. This is referred to as the normal form of the game. "To analyze sequential choices, game theory ordinary uses extensive-form games that is, game trees. However, it is possible to convert nay extensive-form game into a normal-form game that preserves the structure of the extensive form in which rows and columns represent plans for how to play the extensive-form from beginning to end (Stone, 2001, p. 217 in Tema, 2014)." Dealing with the problems and implications of game theory is a central concern for much of the literature on international relations, regional integration, and conflict resolution (Viotti \& Kauppi, 1987 in Tema, 2014). Henceforth, "game theory, whose goal is the formalized analysis of relationships among two or more actors, could assist international relations theoretician's in expanding and comprehensively explain the interactions among the actors and/or players involved (Correa, 2001)."

Application of the data-sets (security and development) based on the content analysis of the related literature for this study are sourced from the Stockholm International Peace Research Institute (SIPRI) from the time period 1997 to 2017. The sampling frame comprises of both print and electronic media, obtained from the SIPRI annual publications and Central Intelligence Agency (CIA) annual World Factbook. The following notations (Sec. $=$ Security; Dev. $=$ Development $)$ are introduced to simplify the construction of the mixed strategy Nash equilibrium matrix table relative to the tenants of game theory. "A mixed strategy involves a situation in which one actor plays 
his/her available pure strategies with certain probabilities. Moreover, it is understood in the context of repeated games in which each actor aim is to keep the other guessing. In furtherance of this, if each actor is an $n$-player, the game has a finite number of pure strategies, hence, there exists at least one equilibrium in a possibly mixed strategy (Nash, 1950).”

\section{Findings and Discussions}

This section of the study presents an analysis of the findings of estimated parameters of noted variables of security - development nexus as part of an inquiry towards a new policy framework that combines China's strategy need for security in Africa and the strive for an enhanced access to the continents mineral resources. Table 1 below presents a summary of results (pay-off function) of China and West as the two main actors relative to security - development nexus on the African continent. We let $p$ be the probability that China chooses $S e c$, so $1-p$ is the probability that the country chooses Dev. On the other hand, we let $q$ be the probability that the West positions itself for Sec. so $1-q$ is the probability that it positions itself for Dev. Henceforth, to find the pay-off of the mixed strategies, we computer the $p$-mix and $q$-mix options, respectively.

Table 1: Pay-off Function

West

\begin{tabular}{|l|c|c|c|}
\hline & Sec. & Dev. & Q-mix \\
\hline Sec. & 50,50 & 80,20 & $50 q+80(1-q)$ \\
\hline Dev. & 90,10 & 20,80 & $90 q+20(1-q)$ \\
\hline p - mix & $50 p+10(1-p)$ & $20 p+80(1-p)$ & \\
\hline
\end{tabular}

China

Source: Authors Compilation, (2020).

Algebraically, China solves the value of $p$ that equated the West's pay-off from positioning itself for Sec. or Dev:

$50 p+10(1-p)=20 p+80(1-p)$, or

$50 p+10-10 p=20 p+80-80 p$, or 
$40 p+10=80-60 p$, or

$100 p=70$, so

$p=70 / 100=.70$.

If China plays Sec. with probability $p=.70$ and $\mathrm{Dev}$. with probability $1-p=.30$, then the West's success rate from Sec. $=50(070)+10(.30)=38 \%$, since this a constant sum game, China's success rate is $100 \%$ - West's success rate $=100-38=62 \%$.

By contrast the West solves for the value of $q$ that equates China's pay-off from playing Sec. or Dev.:

$50 q+80(1-q)=90 q+20(1-q)$, or

$50 q+80-80 q=90 q+20-20 q$, or

$80-30 q=70 q+20$, or

$60=100 q$, so

$q=60 / 100.60$.

If the West positions itself for Sec. with probability $q=.60$ and $D e v$. with probability $1-q=.40$, then China's success rate from Dev. $=90(.60)+20(.40)=62 \%$. Since this is equally a constant sum game, the West success rate is $100 \%$ - China's success rate $=100-62=38 \%$.

The outcome which is strictly a mixed Nash strategy equilibrium in a 2 actor, 2 choice $(2 \times 2)$ game is a $p>0$ and a $q>0$ such that $p$ is a best response by the row actor to column actor's choices, and $q$ is a best by the column actor to the row actor's choices. In table $1, p=.70, q=.60$. The row actor's pay-off (China) was 62 and the column actor's pay-off (West) was 38. Thus, China wins $62 \%$, and the West scores $38 \%$. The pure strategies could be understood as a special case of mixed strategies, where $p$ is chosen from the set $\{0,1\}$ and $q$ is chosen from the set of $\{0,1\}$. For instance, if $p=0$ and $q=1$, then row actor player always plays $D e v$. and column player always plays Sec. In constant sum games, such as the table 1 (pay-off function), China making her opponent (the West) indifferent in expected pay-off terms is equivalent to minimizing their 
opponents ability to recognize and exploit systematic patterns of behavior in this case, an evaluation of the interlocked relationship between security and development as foreign policy strategy on the African continent in terms of their own choice. Similar to the pay-off in table 6, equilibrium 1 is an equilibrium for any belief of China's maximalist $(0<\delta<1)$, but the West's maximalist must assume that the chances of a Chinese minimalist are 0.22 at most. If $\beta>0.22$, then the West's maximalist will prefer to switch to No/Yes. Equilibrium 2 holds only if $\beta<0.3$ and $\delta<0.54$. Equilibrium 3 requires no assumption on $\beta$ but $\delta<0.46$ is required. These beliefs are consistent with Harsanyi (1967-8) postulations, that is:

"there exists a (prior) probability distribution over the types' combinations that induces (as conditional or posterior probability distribution) the values of $\alpha, \beta, \mathrm{y}$, and $\delta$ respectivel. Specifically, the probability of both sides being minimalists or both being maximalists is 0.4. The probability that the West is minimalist, and China is maximalist or vice versa is 0.1 each. In constant sum games, keeping one's opponent indifferent is equivalent to keeping yourself indifferent. Thus, the same policy goal works for finding mixed strategy equilibria in non-constant same games as well, where the actors' interests are not totally opposed to one another. Henceforth, this suggests the game is played repeatedly. In the nutshell, it should be noted that in reality it is assumed only the range of the beliefs, parameters to be common knowledge. Further, since there are three equilibria, games theory does not predict which equilibrium will arise. Moreover, without some additional assumptions, the theory does not claim that an equilibrium will be achieved. Therefore, the inquiry's heuristic is that if a combination of strategies is played for some time, it is an equilibrium. However, in the short run, different players may play equilibrium strategies of different equilibria. In deciding on a policy it seems inconceivable that in a one-shot situation a player will randomize that is being indifferent between several policies, s/he will choose one of them according to a pre-specified probability dictated by the equilibrium, and (stochastically) independent of any parameter of the game. A claim may be made that from an observer's point of view a player may seem to be randomizing. However, such opponent randomizing does not imply that a mixed strategy is played. Henceforth, as part of the study's conclusion, it is postulated that in the spirit of their 
inquiry, the randomization results in the selection of the player's type, who, in turn, plays a pure strategy."

The above outcome buttresses the stance taken by Evans and Newnham (1998, p. 645) and Hollis and Smith (1990, p. 10), that:

"one of the basic assumptions of the realist approach to international relations is that nation-states are motivated only by their own interests. This school of thought emphasizes that nation-states consider the needs and interests of other nation-states only when the other nation-states have the capability to enforce their demands by threatening or performing damaging actions. This means that nation-states are not guided by ethical or humanitarian considerations, and that international law and even treaties and similar formalized agreements do not really restrict the international activities of nation-states."

Game theory finds in the nation-states as described above the closest real-life examples of its abstract constructs. This is the true regardless of whether they are interacting with respect to security, development and/or to economic issues (Brans, 1975; Bierman \& Fernandez, 1998). In game theory, rationality demands that each actor tries to maximize gains or minimize losses under conditions of uncertainty and incomplete information which required each actor to rank order preferences, estimate probabilities, and try to determine and predict what the other actor is going to do.

Relations among nations as commonly denoted from various angles, relate with the interactions among specific actors which range from individuals to nation-states, international organisations, and multinational corporations.

Henceforth, it thus, follows that: "game theory, whose main goal is the formalized analysis of decision-making procedures and relationships among two or more actors, can assist international relations theoreticians and practitioners in the field to explain the interactions among the actors it considers. Therefore, game theory provides specific means not only for understanding different realities but also means in order to influence interactions with broad benefits (Tema, 2014)."

A common assumption in the field of international relations is the fact that choices of actors are interdependent: 
"such interdependence of actions leads to strategic reasoning which becomes quite complex and difficult to unlock even for many simple interactions. Game theory unfolds a comprehensive method that allows in-depth explorations of different political, social, and economic interactions. Given the actors basic preferences related to respective utility and given their strategic environment, game theory helps us to infer how they rank the various actions at their disposal and furthermore it helps us to determine the expected outcomes of the interplay of specific choice (Tema, 2014). Within the discipline of International Relations there are competing theories or theoretical perspectives. In this context, realism is a specific approach of international policies that stresses the competitive and conflictual aspects of the international system."

At the core of the realist assumptions, is the belief that the state is the key actor in international security, development, politics and relations among states (Ray, 2003; Tema, 2014):

"This stance is contradicted by idealism or liberalism which has a general predisposition to emphasize non-state actors and co-operation. Contrary to liberalist claims, realist assumptions consider the principal actors in the geo-political arena to be states, which are mainly concerned with their security needs and act in the pursuit of their own national interests furthermore continuously struggling for more power. Furthermore, the study's application of the framework of security-development nexus and its findings confirms the Chinese President Xi Jinping emphasis on the need to focus on development, which actively improve people's lives and narrow down the wealth gap so as to cement the foundation of security. This thus, brings to the fore a security-development nexus as a framework to understand China's security practices in Africa. This nexus highlights the integration of security and development and views peace and conflict resolution to be the result of successful economic development. Therefore, the core argument is that central to Beijing's security strategy in Africa are not only arms sales, deployment of combat troops, or establishment of military bases, but that equally vital are investments in human resource development through capacity building policies, programmes and projects targeted at achieving tenants' within the SDGs relative to the World Bank's agenda 2030. Thus, the security and development nexus both concerns a general idea of how societal security and development best is achieved and maintained and how the civil and the military in 
international operations should approach crisis, conflicts and other concerns in postconflict countries, failed stead and weak state, that is cooperative."

\section{Conclusion}

The article critically examines the second wave of the contestation and/or scramble for Africa's natural resources. The scramble for the Africa's economic resources by the European countries that started in the colonial period never ceased even after decolonization. The current situation is the emergence of a new non-traditional imperial power - China. The inquiry is conducted within the security-development nexus supplemented by the schools of thought relative to realism, and neo-liberalism. It applied a mixed methodological approached with methods focused on historical research, case study and content analysis as applicable to qualitative philosophy; on the other, hand, game theory as a method relative to quantitative philosophy is applied. Based on its internal history and in shape contrast to the history of the linear approach to Western developmental in which 'development' is understood as a process of biological evolution, signifying the ultimate fulfilling of the process of becoming what one is 'supposed to be.' As it were, 'development' became a key strategy for state-building in the post-colonial societies in which there was an urgent need for both economic growth and political consolidation. Unfettered belief in modernization through 'development' as a fastest and assured path away from prevailing 'underdevelopment.' Importantly, through 'development' so understood, nation-states were to be invented, established, secured and evolved along a linear trajectory of 'progress', following the path forged by former colonial and/or empire power states in Europe. The political and economic elites were the necessary drivers of this process, and 'trickle-down' was the hope for the rest. Accordingly, development was not only driven by the state, but also served to constitute the state. However, the post-colonial world in the 1960/70s did not realize this modernist dream; instead, social and political problems proliferated, unavoidably calling into question the teleology of 'development' experiment as championed by the West underpinned by Chicago consensus. The philosophical strand of the Chicago consensus is the principle that security studies focused their attention on the control, threat and/or use of force. The prevailing view was that since states are both the main users of force and the main targets of force, security should thus, be state centric and military centric. Henceforth, as a result of this understanding, security came to be understood as mainly related to the state and/or the military Therefore, the concept of security has mostly been associated 
with national security and external military threats to the nation state. However, the Chinese approach and relationship with Africa is based on the new concepts such as human security espoused and therefore, takes note of a multi-dimensional view of security and includes seven elements of security: economic security, health security, food security, environmental security, personal security, community security, and political security. The primary focus is on the military in the first dimension whilst, in the second dimension given less importance. The emphasis on national security seen before have not lost importance, but made equally important to international and global security due to the recognition that the world today is inter-dependent politically, socially and economically. The axe has indeed equally been placed on regions and institutions as new security actors; the tendency for emerging powers to via for control of resource markets is being repeated in Africa, where the Chinese are competing for strategic minerals to spur economic growth and development back in China.

\section{References}

Agha, J. H. (1976). What State for the Palestinians? J. Palest. Stud. 6, 3-38.

Anderson, N. A. (2012), Redefining International Security: Bringing Intent Back In. Josef Korbel Journal of Advanced International Studies, (4), 27 - 47.

Ary, D. Jacob, C. L., Razavieh, A., \& Sorensen, C. (2006). Introduction to research in education. Belmont: Thomson Higher Education.

Badie, B., Schlosser. D.B. \& Morlino, L. (2011). Liberalism in International Relations. Retrieved from: https://pdfs.semanticscholar.org/648a/ff3504a0ff46e1a255bc19bdf6b35225d292.pdf

Baldwin, D. A. (1997). The Concept of Security. Review of International Studies. (23), 23 - 26.

Bennett, P. \& Nicholson, M. (1994). Formal Methods of Analysis in IR", in Groom, A. J. R. and Light, Margot (eds.), Contemporary International Relations: A Guide to Theory, Pinter Publishers: New York, NY. 
Bergström, G \& Boréus, K. (2005). 'Innehållsanalys”. In: Bergström, G and Boréus, K (eds), 2005, Textens mening och makt, metodbok i samhällsvetenskaplig text- och diskursanalys. Lund: Studentlitteratur.

Benabdallah, L. (2016). China's Peace and Security Strategies in Africa: Building Capacity is Building Peace? Retrieved from: http://asq.africa.ufl.edu/files/v16a3.Lina_.HD_.pdf

Bernard, F. (1998). What is Security? Why the Debate Matters. National Security Studies Quarterly, (4), $46-67$.

Bierman H. S. \& Fernandez, L. (1998). Game Theory with Economic Applications, (2 ${ }^{\text {nd }}$. Ed.). Addison Wesley: Reading, MA.

Brams, Steven, J. (1975) "Game Theory and Politics", The Free Press: New York, NY

Center for Strategic and International Studies (CSIS) \& Association of the United States Army, (2002). Post-Conflict Reconstruction Task Framework. Retrieved from:

https://www.ausa.org/sites/default/files/RAMP_2002_Post-Conflict-Reconstruction-TaskFramework.pdf

Chandler, D., (2007). The Security-development Nexus and the Rise of Anti-Foreign Policy. Journal of International Relations and Development, 10(4), 362 - 386.

Chris, A. \& Large, D. (2013). “China's Evolving Policy towards Peace and Security in Africa: Constructing a New Paradigm for Peace Building? Institute of Peace and Security Studies, 16-28.

Conrad, F. C., \& Serlin, C. R. (2006). The Sage handbook for research in education. California: Sage Publication, North: ERDC Press.

Correa, H. (2001). Game Theory as an Instrument for the Analysis of International Relations. Retrieved from: http://www.ritsumei.ac.jp/acd/cg/ir/college/bulletin/vol14-2/14-2hector.pdf

Cresswell, W. J. (1994). Research design, qualitative and quantitative approaches. California: SAGE Publications.

de Janvry, A. \& Kanbur, R. (2006). Poverty, Inequality, and Development: Essays in Honor of Erik Thorbecke. Berlin: Springer.

Denzin N. \& Lincoln Y. (2000). Handbook of Qualitative Research. London: Sage Publication Inc.

Denzin, K. N., \& Lincoln, S. Y. (2008). The landscape of qualitative research. California: Sage Publication. 
DeVellis, R. F. (2003). Scale development: theory and application ( $2^{\text {nd }}$ Ed.). Thousand Oaks, CA: Sage Publications, Inc.

Dixit, A. \& Skeath, S. (1999). Games of Strategy, W. W. Norton \& Co.: New York, NY.

Drexhage, J \& Murphy, M. (2010). The Origins of Sustainable Development Sustainable: From Brundtland to Rio. New York: United Nations.

Escobar, A. (1995). Encountering Development: The Making and Unmaking of the Third World. Princeton, NJ: Princeton University Press.

Esteva, G. (1992). Development, in Wolfgang Sachs, ed., The Development Dictionary: A Guide to Knowledge as Power. London: Zed (6-25).

Evans, G. \& Newnham, J. (1998). Dictionary of International Relations, Penguin Putnam Inc.: New York, NY.

Frank, A. G. (1969). Capitalism and Underdevelopment in Latin America. New York: New York University Press.

Friedman, J. (1992). Empowerment. Oxford: Blackwell.

Garraghan, G. J. (1946). A Guide to Historical Method. New York: Fordham University Press.

Gottschalk, L. (1951). Understanding History. New York: Alfred A. Knopf.

Hamel, Jacques (1993). Case study methods. Thousand Oaks: Sage.

Harsanyi, J.C. (1967-8), Games with Incomplete Information Played by ‘Bayesian' Players, I-III, Management Science, 14, 159-182, 320-334, 486-502.

Heyvaert, M., Maes, B. \& Onghena, P. (2011). Mixed Methods Research Synthesis: Definition, Framework, and Potential. Retrieved from: https://ppw.kuleuven.be/mesrg/documents/pdfmieke-heyvaert/heyvaert-et-al-2011.pdf

Hollis, M. \& Smith, S. (1990). Explaining and Understanding International Relations, Oxford University Press: New York, NY.

Hsieh, H. F. \& Shannon, S.E. (2005). Three Approaches to qualitative Content Analysis. Qualitative Health Research, 15(9), 1277-1288.

Garfinkle, A. M. (1983). Sources of al-Fatah mutiny. Orbis, 27, 603-640. 
International Peace Academy, (2004). Strengthening the Security- Development Nexus: Assessing Internal Policy and Practice since the 1990s. Retrieved from: http://www.un.org/esa/peacebuilding/Library/Strengthening_SecDev_Nexus_IPA.pdf.

Jinping, Xi. (2015b). The Forum of China-Africa Cooperation is a summit held every three years by Chinese and African leaders. Retrieved from: http://www.focac.org/eng/ltda/.

Johanson, V. (2014). The Security and Development Nexus: A Policy Analysis. Retrieved from: https://www.diva-portal.org/smash/get/diva2:784285/FULLTEXT01.pdf

Kant, I. (1781). Critique of Pure Reason. Cambridge University Press: London.

Kracauer S. (1952). Suggests that the Process of Quantification is an Attempt not to Infer Meaning but, Rather, to Explore Usage. Public Opinion Quarterly, 16(4), 631-642.

Lake, D. H. \& Powell, R. (1999). International Relations: A Strategic-Choice Approach, in Lake, David H. \& Powell, Robert (eds.), Strategic Choice and International Relations, Princeton University Press: Princeton, NJ.

Lock, J. (1689). Two Treatises of Government. Cambridge University Press: London.

Mazzini, G. (1860). The Duties of Mana and Other Essays. J.M. Dent \& Sons: London.

Mishal, S. (1986). The PLO Under Arafat: Between Gun and Olive Branch. Yale Univ. Press: New Haven, Connecticut.

Mishal, S., Schmeidler, D. \& Sened, I. (1990). Israel and the PLO: A Game with Differential Information. Science Direct, (1), 336 - 357. Retrieved from:

https://www.sciencedirect.com/science/article/pii/B9780123701824500234?via\%3Dihub

Montesquieu, B. (1748). The Spirit of Law. New York: The Colonial Press.

Nash, J. F. (1950). Equilibrium Points in N-Person Games. Proceedings of the National Academy of Sciences. 36(1), $48-49$.

Nisbet, R. (1980). History of the Idea of Progress. London: Heinemann.

Ohlin, J. D. (2011). Nash Equilibrium and International Law. Cornell Law Faculty Publications, 96(11-20), $869-900$. 
Pietersee, J. N. (2000). After Post-Development. Third World Quarterly, 21(2), 175-191.

Palestine National Council. (1974). Political Program for the Present Stage of the Palestine Liberation Organization Drawn up by the Palestine National Council. J. Palest. Stud. 4, 224-226.

Poplak, R. (2016, December 22). The new scramble for Africa: How China became the partner

of choice. Retrieved from The Guardian: https://www.theguardian.com/global-developmentprofessionals-

network/2016/dec/22/the-new-scramble-for-africa-how-china-became-the-partner-of-choice

Poundstone, W. (1993). Prisoners' Dilemma, Anchor Books: New York, NY.

Prebisch, R. (1950). The Economic Development of Latin America and Its Principal Problems. New York: United Nations.

Rahnema, M. (1997). 'Towards Post-Development: Searching for Signposts, A New Language and New Paradigm', in Majid Rahnema \& Victoria Bawtree, eds, The Post-Development Reader. London: Zed (337-404).

Ray, A. K. (2003). International Relations: A Critique of the Realist Theory. India International Centre Quarterly, 30(2), 110 - 128.

Reynolds, P. A. (1994). An Introduction to International Relations" (3 ${ }^{\text {rd }}$ ed.), Longman Publishing: New York, NY.

Rostow, W. W. (1962). The Stages of Economic Growth: A Non-Communist Manifesto. Cambridge: Cambridge University Press.

Schumacher, J. A. (1947). The Creative Response in Economic History. The Journal of Economic History, 7(2), $149-159$.

Schumacher, E. F. (1973). Small Is Beautiful: A Study of Economics As If People Mattered. London: Blonde \& Briggs.

Shafer, R. J. A. (1974). Guide to Historical Method. Illinois: The Dorsey Press.

Shank, G. (2002). Qualitative Research. A Personal Skills Approach. New Jersey: Merril Prentice Hall.

Smith, A. (1776). An Inquiry Into The Nature and Causes of The Wealth of Nations. Retrieved from:

http://www.ultimorecurso.org.ar/drupi/files/Adam\%20Smith\%20\%27The\%20Wealth\%20of\%20 Nations\%27.pdf 
Stake, R. (1995). The art of case research. Thousand Oaks, CA: Sage Publications

Stern, M. \& Ojendal, J. (2010). Mapping the Security - Development Nexus: Conflict, Complexity, Cacophony, Convergence? Retrieved from:

http://www.sagepub.co.uk/journalsPermissions.nav

Sumner, A \& Tribe, M. (2008). What is Development? Development Studies Theories Methods in Research and Practice. London: Sage publications.

Tema, M. (2014). Basic Assumptions in Game Theory and International Relations. International Relations Quarterly, 5(1), $1-4$.

United Nations. (2005). Introduction in Larger Freedom: Towards Development, Security and Human Rights for All. Retrieved from:

http://www.ohchr.org/Documents/Publications/A.59.2005.Add.3.pdf.

von Neumann, J. \& Morgenstern, O. (1994). Theory of Games and Economic Behavior.

Retrieved from:

https://pdfs.semanticscholar.org/0375/379194a6f34b818962ea947bff153adf621c.pdf

Wallerstein, I. (1974). The Modern World-System, Vol. I: Capitalist Agriculture and the Origins of the European World-Economy in the Sixteenth Century. New York \& London: Academic.

World Commission on Environment and Development. (1987). Our Common Future. Oxford and New York: Oxford University Press.

Yizhou, W. (2013). Creative Involvement: The Evolution of China's Global Role. Beijing: Peking University Press.

Werle, F. \& Andersson, I. (2012). "Metod". En kvalitativ analys av jämställdhetsplaner i offentlig verksamhet - Vad säger de egentligen?. Örebro University: Departement of Health and Medical science.

Wolfers, A. (1991). Actors in International Politics, in Olson, William C. (ed.) The Theory and Practice of International Relations ( $8^{\text {th }}$ ed.), Prentice Hall Inc., Englewood, NJ.

Yin, R. (1984). Case study research: Design and methods (1 ${ }^{\text {st }}$ Ed.). Beverly Hills, CA: Sage Publishing.

Yin, R. (1994). Case study research: Design and methods ( $2^{\text {nd }}$ Ed.). Beverly Hills, CA: Sage Publishing. 